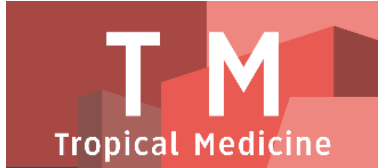

PAPER - OPEN ACCESS

\title{
Pengaruh Penambahan Ekstrak Daun Piladang (Solenostemon scutellarioides (L.) Codd) Terhadap Kualitas Minyak Ikan
}

\author{
Author : Verawati \\ DOI $\quad: 10.32734 /$ tm.v1i3.276 \\ Electronic ISSN : 2623-0542 \\ Print ISSN : 2623-0550
}

Volume 1 Issue 3 - 2018 TALENTA Conference Series: Tropical Medicine (TM)

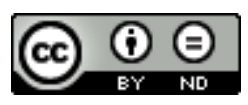

This work is licensed under a Creative Commons Attribution-NoDerivatives 4.0 International License.

Published under licence by TALENTA Publisher, Universitas Sumatera Utara
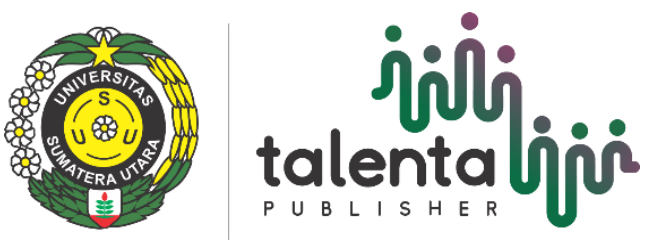


\title{
talentaili
}

Available online at https://talentaconfseries.usu.ac.id

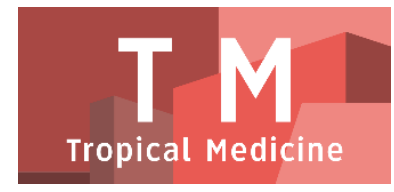

\section{Pengaruh Penambahan Ekstrak Daun Piladang (Solenostemon scutellarioides (L.) Codd) Terhadap Kualitas Minyak Ikan}

\author{
Verawati* ${ }^{a *}$ Miftahur Rahmi, Gina Desriyanti \\ ${ }^{a}$ Sekolah Tinggi Farmasi Indonesia Yayasan Perintis Padang \\ verawati81apt@gmail.com
}

\begin{abstract}
Abstrak
Solenostemon scutellarioides (L.) Codd dikenal juga dengan nama Piladang (Sumatera Barat) merupakan tanaman obat tradisional yang memiliki berbagai aktivitas salah satunya antioksidan. Antioksidan dapat digunakan untuk mencegah oksidasi dai lemak tak jenuh yang terdapat dalam inyak/lemak sehingga dapat menjaga kualitas minyak/lemak tetap baik dan tahan lama. Penelitian ini bertujuan untuk menentukan pengaruh penambahan Ekstrak daun piladang terhadap kualitas minyak ikan (oleum iecoris aselli). Kulaitas minyak ikan ditentukan dengan parameter bilangan asam, bilangan iod dan bilangan peroksida menggunakan metode titrasi. Daun kering Piladang diekstraksi dengan cara sokletasi menggunakan pelarut etanol 70\%. Ekstrak daun piladang ditambahkan pada minyak ikan dengan konsentrasi $0 \%, 1 \%, 3 \%$ dan 5\% dengan lama waktu penyimpanan 1,3,5 dan 7 hari. Hasil penelitian menunjukkan bahwa penambahan ekstrak daun piladang dapat memperbaiki kualitas minyak ikan dengan cara menurunkan bilangan asam, meningkatkan bilangan iod dan menurunkan bilangan peroksida. Berdasarkan analisa statistikANOVA dua arah diikuti uji lanjut Duncanmenunjukkan perbedaan nyata antara nilai parametr kualitas minyak ikan terhadap konsentrasi dan lama waktu simpan Semakin tinggi penambahan konsentrasi ekstrak daun piladang maka semakin baik kualitas minyak ikan.
\end{abstract}

Kata Kunci : Solenostemon scutellarioides, piladang, fenolat, kualitas minyak

\begin{abstract}
Solenostemon scutellarioides (L.) Codd known as Piladang (in Sumatera Barat) is a traditional medicinal plant that has various activities one of which is an antioxidant. One use of antioxidants is to prevent oxidation of the unsaturated fatty acids contained in the oil / fat so as to maintain the quality of oil / fat remains good and durable. This study aimed to determine the effect of the addition of piladang leaf extract (Solenostemon scutellarioides (L.) Codd) on the quality of fish oil (oleum iecoris aselli). The quality of fish oil were observed by parameters such acid number, iodine number, and peroxide number by titration method. Dried Piladang leaves were extracted by soxhletation method using ethanol $70 \%$ as a solvent. The addition of piladang leaf extract on fish oil was done with concentration $0 \%, 1 \%, 3 \%$ and $5 \%$ with storage period $1,3,5$ and 7 days. The experimental result showed that addition of piladang leaf extract could improve the quality of fish oil by decreasing the number of acids, increasing the number of iod, and the decrease of peroxide numbers. Based on statistical analysis using two-way ANOVA followed by Duncan test has found that significant difference between values of fish oil quality parameters to extract concentration and period of storage time. The higher of the concentration of the extract will further improve the quality of fish oil
\end{abstract}

Keywords : Solenostemon scutellarioides, piladang, phenolic, oil quality

\section{Pendahuluan}

Daun piladang (Solenostemon scutellarioides (L.) Codd) merupakan obat tradisional yang sudah digunakan oleh masyarakat di berbagai wilayah di Indonesia. Berdasarkan eksplorasi tumbuhan obat oleh [1] dinyatakan bahwa daun piladang digunakan sebagai obat ambeien, diabetes melitus, demam, diare (sakit perut), datang bulan terlambat, dan bisul. Daun piladang mempunyai aktivitas antioksidan dengan kandungan kimia seperti fenolat, flavonoid, minyak atsiri, lemak, fitosterol, kalsium, oksalat, alkaloid, dan mineral [2,3,4].

Penggunaan antioksidan untuk mengatasi oksidasi dari bahan makanan telah banyak digunakan, contohnya penggunaan pada berbagai minyak seperti minyak nabati (minyak makan, minyak goreng, minyak kelapa) dan minyak hewani (minyak ikan). Minyak ikan memiliki kandungan asam lemak tak jenuh paling tinggi dibandingkan dengan jenis minyak lainnya. Minyak ikan kaya akan PUFA (Poly Unsaturated Fatty Acid) atau asam lemak tak jenuh khususnya omega-3 yaitu EPA (Eicosapentaenoic Acid) dan DHA (Docosahexaenoic Acid) [5]. Kandungan inilah yang menyebabkan minyak ikan menjadi kurang stabil, sebab mudah teroksidasi. Proses oksidasi akan semakin meningkat dengan adanya panas, cahaya dan oksigen. [6]. Pada penelitian ini dilakukan evaluasi untuk melihat pengaruh penambahan ekstrak daun piladang terhadap kualitas minyak ikan dengan parameter analisa bilangan asam, bilangan iod, dan bilangan peroksida. 


\section{Bahan dan Metode}

\subsection{Alat dan Bahan}

Peralatan antara lain rotavapor, alat soklet, buret, hotplate, alat-alat gelas standar laboratorium. Bahan yang digunakan pada penelitian ini adalah daun piladang (Solenostemon scutellarioides (L.) Codd), minyak ikan, air suling, asam asetat glasial, kloroform, KI jenuh, Na2S2O3, larutan pati, etanol 70\%, indikator phenolftalein, $\mathrm{KOH}$, aluminium foil dan kertas saring.

\subsection{Pembuatan Ekstrak Daun Piladang}

Serbuk kering daun piladang diambil sebanyak $150 \mathrm{~g}$ disokletasi dengan etanol $70 \%$ sebanyak 1 liter sampai tetesan terakhir hasil sokletasi tidak berwarna lagi. Ekstrak cair hasil sokletasi disaring kemudian filtrat diuapkan dengan rotary evaporator sehingga diperoleh ekstrak kental.

\subsection{Pembuatan campuran ekstrak dan minyak ikan}

Sampel uji berupa campuran minyak ikan dan ekstrak piladang seperti yang tercantum dalam tabel 1.

Tabel 1. Komposisi campuran ekstrak daun piladang dan minyak ikan

\begin{tabular}{ccc}
\hline Sampel & Ekstrak daun piladang $(\mathrm{g})$ & Minyak ikan $(\mathrm{g})$ \\
\hline $\mathrm{C} 0$ & 0 & 5 \\
$\mathrm{C} 1$ & 0,05 & 5 \\
$\mathrm{C} 2$ & 0,15 & 5 \\
$\mathrm{C} 3$ & 0,25 & 5 \\
\hline
\end{tabular}

Minyak ikan dan ekstrak dicampur homogen dalam lumpang, kemudian dimasukkan ke dalam wadah kaca dan disimpan di tempat terlindung cahaya matahari selama 1, 3, 5 dan 7 hari.

\subsection{Evaluasi Kualitas Minyak}

Parameter pengujian kualitas minyak antara lain terhadap bilangan asam (metode titrasi asam basa), bilangan iod (metode Hanus) dan bilangan peroksida (Titrasi iodometri) [7]. Pengujian dilakukan dengan tiga kali pengulangan

\section{Hasil dan Pembahasan}

Ekstraksi daun piladang kering dilakukan dengan metode sokletasi dan diperoleh ekstrak sebanyak 10,52 g (7,01\%). Ekstrak daun piladang diperiksa secara organoleptis dan kimia. Secara organoleptis ekstrak berbentuk massa kental, berwarna coklat kehitaman, memiliki bau khas aromatik dan rasa yang pahit. Pemeriksaan terhadap kandungan fitokimia menunjukkan bahwa ekstrak daun piladang positif mengandung alkaloid, flavonoid, fenolat, saponin, dan steroid.

Ekstrak daun piladang dilaporkan memiliki kandungan fenolat yang tinggi dan aktif sebagai antioksidan [4]. Aktivitas antioksidan ini diaplikasikan terhadap minyak ikan dengan tujuan memberikan tahanan terhadap minyak ikan sehingga tetap terjaga kualitasnya. Kualitas minyak ikan dapat ditentukan dengan beberapa parameter antara lain bilangan asam, bilangan iod dan bilangan peroksida. Pada penelitian ini, ketiga jenis parameter tersebut ditentukan dengan metode titrasi.

Ekstrak diencerkan menggunakan alkohol (1:1) dan ditambahkan kepada minyak sedikit demi sedikit dalam lumpang panas dengan menggerus sampai homogen. Berdasarkan hasil penelitian menunjukkan semakin tinggi konsentrasi ekstrak daun piladang akan menurunkan bilangan asam, meningkatkan bilangan iod dan menurunkan bilangan peroksida. Penyimpanan yang semakin lama menunjukkan penurunan kualitas minyak yaitu bilangan asam semakin meningkat, bilangan iod menurun dan bilangan peroksida meningkat. Penambahan ekstrak piladang memberikan profil kualitas minyak yang lebih baik dibandingkan minyak tanpa ekstrak.

Tabel 2. Hasil penentuan bilangan asam, bilangan iod dan bilangan peroksil dari minyak ikan

\begin{tabular}{|c|c|c|c|c|c|c|c|c|c|c|c|c|}
\hline \multirow[t]{2}{*}{ Sampel } & \multicolumn{4}{|c|}{$\begin{array}{l}\text { Bilangan asam hari ke- } \\
(\mathrm{mg} \mathrm{NaOH} / \mathrm{g})\end{array}$} & \multicolumn{4}{|c|}{$\begin{array}{l}\text { Bilangan Iod hari ke- } \\
\text { (g I2/100g) }\end{array}$} & \multicolumn{4}{|c|}{$\begin{array}{c}\text { Bilangan peroksida hari ke- } \\
(\mathrm{meq} / \mathrm{kg})\end{array}$} \\
\hline & 1 & 3 & 5 & 7 & 1 & 3 & 5 & 7 & 1 & 3 & 5 & 7 \\
\hline $\mathrm{CO}$ & 0,72 & 0,88 & 1,44 & 2,16 & 153,19 & 127,66 & 114,89 & 89,36 & 9,63 & 10,03 & 10,43 & 11,07 \\
\hline C1 & 0,48 & 0,63 & 1,11 & 1,19 & 202,24 & 174,96 & 164,32 & 139,04 & 6,61 & 9,38 & 9,74 & 10,33 \\
\hline $\mathrm{C2}$ & 0,39 & 0,47 & 0,78 & 0,93 & 210,70 & 198,31 & 185,91 & 173,51 & 5 & 7,41 & 7,56 & 7,64 \\
\hline C3 & 0,15 & 0,30 & 0,38 & 0,46 & 218,85 & 206,69 & 182,37 & 133,74 & 3,69 & 6,28 & 6,54 & 6,69 \\
\hline
\end{tabular}

Bilangan asam merupakan sebuah indikator penting kualitas minyak ikan. Bilangan asam dinyatakan sebagai jumlah $\mathrm{NaOH}$ yang dibutuhkan untuk menetralkan asam lemak bebas dalam minyak. Asam lemak bebas merupakan hasil dari minyak yang 
terurai yang disebabkan oleh reaksi hidrolisis atau faktor fisik lainnya seperti cahaya dan panas. Asam lemak bebas sebenarnya telah terdapat secara alami dalam minyak tetapi dapat meningkat akibat reaksi hidrolisis yang disebabkan oleh kandungan air, enzim atau kontaminan mikroba.. Keberadaan asam lemak bebas biasanya dijadikan indikator awal terjadinya kerusakan minyak. Pembentukan asam lemak bebas akan mempercepat kerusakan oksidatif minyak karena asam lemak bebas mudah teroksidasi dibandingkan dengan bentuk esternya . Bilangan asam minyak setelah ditambah dengan ekstrak daun piladang mengalami penurunan. Hal ini kemungkinan disebabkan karena adanya penghambatan kerja enzim lipase dalam memecah ester trigliserida atau terbentuknya senyawa ester antara asam-asam lemak bebas dengan alkohol yang terkandung dalam ekstrak daun piladang. Bilangan asam minyak ikan yang telah ditambahkan ekstrak daun piladang memenuhi persyaratan Farmakope Indonesia yaitu tidak lebih dari 1,2 [7].

Bilangan iod adalah ukuran dari jumlah asam lemak tidak jenuh dalam minyak. Ketidakjenuhan asam lemak akan menyebabkan minyak kurang stabil dan lebih rentan terhadap reaksi oksidasi yang dapat menghasilkan radikal bebas. Asam lemak tidak jenuh mampu mengikat iod dan membentuk senyawa yang jenuh. Banyaknya iod yang diikat menunjukkan banyaknya ikatan rangkap yang terdapat pada minyak. Hal ini menunjukkan bahwa semakin tinggi bilangan iod maka semakin baik kualitas minyak atau lemak. Penurunan bilangan iod berhubungan dengan terbentuknya senyawa peroksida akibat oksidasi dan polimerisasi oksidasi yang terjadi. Hal ini terjadi karena ikatan rangkap pada asam lemak tidak jenuh semakin berkurang karena teradisi oleh atom oksigen membentuk peroksida. Bilangan iod minyak ikan semakin tinggi dengan penambahan ekstrak daun piladang dan beberapa perlakuan melebihi nilai dalam persyaratan di Farmakope Indonesia yaitu antara 150-180 [7]. Hal ini bisa saja disebabkan adanya senyawa-senyawa tak jenuh dan zat antioksidan dalam ekstrak yang bereaksi dengan iod pada saat titrasi.

Bilangan peroksida didefinisikan sebagai berat oksigen aktif yang terkandung dalam minyak atau lemak. Bilangan peroksida menentukan tingkat oksidasi minyak dan memberikan indikasi tingkat kerusakan minyak atau lemak. Banyaknya peroksida yang ada dalam minyak mencerminkan tingkat oksidasi yang tinggi dan cenderung akan menjadi tengik. Bilangan peroksida minyak ikan semakin turun dengan penambahan ekstrak daun piladang.

Analisis statistik dilakukan dengan bantuan aplikasi SPSS 16.0 dengan analisa varian dua arah. Hasil pengujian statistis anova dua arah menunjukkan bahwa ekstrak daun piladang pada parameter bilangan asam, bilangan iod dan bilangan peroksida yang ditandai dengan nilai signifikan $\mathrm{P}<0,05$, artinya adanya perbedaan secara bermakna antara konsentrasi dan lama penyimpanan. Hasil uji lanjut Duncan memperlihatkan bahwa terdapat perbedaan yang cukup nyata dari hari pertama sampai hari ke tujuh. Data ini menunjukkan bahwa selama proses penyimpanan terjadi penurunan kualitas minyak, sehingga perlu diperhatikan cara penyimpanan minyak yang baik seperti dalam wadah kaca amber, terlindung dari cahaya matahari langsung, tertutup rapat, menghindari kontaminasi kelembaban, air dan sebagainya.

Berdasarkan hasil penelitian dapat diambil kesimpulan bahwa ekstrak daun piladang dapat memperbaiki kualitas minyak ikan dengan parameter penurunan bilangan asam, peningkatan bilangan iod dan penurunan bilangan peroksida.

\section{Daftar Pustaka}

[1] Zulfahmi, Bakhendri, S. 2010. Eksplorasi Tanaman Obat di Kabupaten Kampar, Jurnal Agroteknologi, Volume 1 No 1, hal 31-38.

[2] Dalimartha, S., 2008, Atlas Tumbuhan Obat Indonesia. Jilid 2. Trubus Agriwidya. Jakarta

[3] Hardiyanti, Y., Djaswir D., Adlis S., 2013. Ekstraksi dan Uji Antioksidan Senyawa Antosianin dari Daun Miana (Coleus scutellarioides (L). Benth) Serta Aplikasi Pada Minuman, Jurnal Kimia Unand, Vol. 2 No 2, Hal. 44-50.

[4] Verawati, Arel, A., Arfianisa, R., 2016. Kandungan Fenolat Total Ekstrak Daun Piladang (Solenostemon scutellarioides (L) Codd). SCIENTIA Jurnal Farmasi dan Kesehatan. 6(2). 79-83.

[5] Sahena, F., I.S.M. Zaidul, S. Jinap, A.M. Yazid, A. Khatib, N.A.N. Norulaini. 2010. Fatty acid compositions of fish oil extracted from different parts of Indian mackerel (Rastrelliger kanagurta) using various techniques of supercritical $\mathrm{CO}_{2}$ extraction. Food Chemistry, 120:879-885.

[6] Ketaren, S., 2008. Minyak dan Lemak Pangan. Cetakan Pertama. Universitas Indonesia Press. Jakarta.

[7] Departemen Kesehatan RI, 1995. Farmakope Indonesia IV. Depkes RI. Jakarta 